\title{
How Original a Work is the Tractatus Logico-Philosophicus?
}

\author{
LAURENCE GOLDSTEIN
}

\section{First Blush}

My experience on first reading the Tractatus $^{1}$ was, I suspect, similar to that of many others. I was young and impressionable; the text seemed unlike anything else I had ever read and completely unlike any other philosophical treatise that I had encountered. The propositions appeared to have an almost ethereal quality, each one pregnant, momentous and dauntingly impenetrable, yet the whole was tightly organized, its elegant structure disclosed by a numbering system which indicated the logical role of each proposition in the construction.

${ }^{1}$ I shall use the following abbreviations for Wittgenstein's works:

N Notebooks 1914-16, G. E. M. Anscombe (trans.) (Oxford: Blackwell, 1961).

CV Culture and Value, Revised Edition, G. H. von Wright (ed.) (Oxford: Blackwell, 1998).

P Prototractatus, B. F. McGuinness, T. Nyberg, G. H. von Wright (eds) (London: Routledge and Kegan Paul, 1971).

T Tractatus Logico-philosophicus, C. K. Ogden and F. P. Ramsey (trans.) (London: Routledge and Kegan Paul, 1922). I also refer to the translation by D. Pears and B. F. McGuinness (London, Routledge and Kegan Paul, 1961). $R L F$ 'Some Remarks on Logical Form', Proceedings of the Aristotelian Society, supp. Vol. 9 (1929), 162-71.

$L E$ 'A Lecture on Ethics' (Heretics Club, Cambridge, 1930) Philosophical Review 74 (1965), 3-12; reprinted in J. Klagge and A. Nordmann (ed.), Philosophical Occasions 1912-1951 (Indianapolis: Hackett, 1993), 36-44.

PR Philosophical Remarks, R. Rhees (ed.) (Oxford: Blackwell, 1965).

WVC Wittgenstein and the Vienna Circle, B. F. McGuinness (ed.) (Oxford: Blackwell, 1967).

LA Lectures and Conversations on Aesthetics, Psychology and Religious Belief, C. Barrett (ed.) (Berkeley: University of California Press, 1970). LRKM Letters To Russell, Keynes and Moore, G. H. von Wright (ed.) (Oxford, Blackwell, 1974).

PI Philosophical Investigations (Oxford: Blackwell, 1953). 


\section{Laurence Goldstein}

After working on the book for some time and coming to see the historical importance of Wittgenstein's views as a reaction to the logico-mathematical doctrines of Frege and Russell, my initial opinion was confirmed-here was a classic of twentieth century philosophy, a text exhibiting the power of logical analysis, while simultaneously drawing on a rich Austro-German tradition in the philosophy of mind and language. This view is, I suspect, shared by most philosophers. It may now seem amazing that Wittgenstein experienced great difficulty in finding a publisher, ${ }^{2}$ for as soon as the monograph appeared in print, it was rapturously acclaimed, and received plaudits from luminous contemporaries in Cambridge, Vienna and elsewhere. Russell concludes his introduction to the book with the counsel '.. to have constructed a theory of logic which is not at any point obviously wrong is to have achieved a work of extraordinary difficulty and importance. This merit, in my opinion, belongs to Mr. Wittgenstein's book, and makes it one which no serious philosopher can afford to neglect' $(T, 23)$. In the eighty years since its publication, the Tractatus has generated an enormous exegetical literature, the most recent controversy concerning whether it is to be read resolutely or irresolutely. ${ }^{3}$ That so short a text should generate so vigorous a debate is testimony, surely, to the work's lasting value. Few would dissent from Peter Hacker's verdict that the book is a masterpiece, albeit a flawed one. ${ }^{4}$

${ }^{2}$ See pp. 11-29 of von Wright's 'Historical Introduction' to $P$.

${ }^{3}$ For a collection of essays all but one of which reads the text resolutely, see A. Crary and R. Read (eds), The New Wittgenstein (London: Routledge, 2000). The exception is P. Hacker, 'Was he Trying to Whistle it?' (pp. 353-88), who adds a number of anti-resolutist points in his 'Philosophy' in H-J. Glock (ed.), Wittgenstein: A Critical Reader (Oxford: Blackwell, 2001), 322-47, esp. 327-31. Another penetrating critique of the resolute reading is $\mathrm{P}$. Sullivan, 'On trying to be resolute: a response to Kremer on the Tractatus', forthcoming in European Fournal of Philosophy, April 2002. A resolute reading is one that does not flinch; it takes absolutely seriously Wittgenstein's declaration at $T 6.54$ that all the preceding propositions in the body of the book are nonsensical. There is not, resolute readers say, illuminating or deep nonsense, but only plain, unadulterated gibberish, so Wittgenstein, in writing the Tractatus, was illustrating, with heavy irony, the mire into which Philosophy sinks when pursued in the traditional way.

${ }^{4}$ P. Hacker, Wittgenstein's Place in Twentieth Century Analytic Philosophy (Oxford: Blackwell, 1996), 22-38. 


\section{How Original a Work is the Tractatus Logico-Philosophicus?}

\section{The antecedents of certain Tractarian ideas}

But is it? How great, how original, is the Tractatus? The style and presentation is, of course, compelling, but the bubble of one's initial enthusiasm is pierced when one discovers that there is a precedent for the numbering system in Russell and Whitehead's Principia Mathematica and discovers also that the style of writing echoes that of earlier philosophers whom Wittgenstein had read. On the latter point, Brian McGuinness remarks that in detail, [The Tractatus] retains many of the features of the Zibaldone, the series of notebooks of aphoristic paragraphs from which it is drawn. In them, as in the collections of aphorisms by Schopenhauer and Lichtenberg, which must to some extent have served as a model, there is only a very loose connexion between the topics treated in the course of a day or a section's. However, McGuinness goes on to make the important claim that Wittgenstein saw the work as both literary and philosophical and that '[o]ne aspect of its literary character is that, like a poem, it is not an indifferent vehicle for something expressible in other ways but shows or conveys something unique by its own form of expression' (op. cit., 302). ${ }^{6}$ It may have come as a disappointment to a jejune adolescent to discover that a

B. F. McGuinness, Wittgenstein: A Life. Young Ludwig (1889-1921) (London: Duckworth, 1988), 300. Wittgenstein himself notes an influence on his writing style. At $Z, \S 712$, he remarks in parentheses 'The style of my sentences is extraordinarily strongly influenced by Frege. And if I wanted to, I could establish this influence where at first sight no one would see it'.

6 McGuinness, op. cit, 302. In his development of this claim, McGuinness offers a 'resolute' reading of the text. He says that one can see Wittgenstein's whole early philosophy 'as a kind of mystic revelation', and that the text provides something 'like an initiation into the mysteries, and when they are reached it can be forgotten' (p. 303). This interpretation may seem to be justified by the aforementioned $T, 6.54$, where Wittgenstein famously says that his propositions (i.e., the propositions of the Tractatus) are to be used as steps of a ladder that, once climbed, brings us to a vantage point from where it is possible to 'see the word aright'. From this vantage point it is possible to see that the ladder propositions themselves are nonsensical, and can be tossed away. McGuinness' reading is a possible, but highly improbable one. Although it is true that the Tractatus does achieve dramatic literary effect, it is not the case (pace McGuinness) that the message is inseparable from the literary medium. Wittgenstein himself makes this clear when, in a conversation with Maurice Drury, he confesses that '[e]very sentence in the Tractatus should be seen as the heading of a chapter needing further exposition. My present style is quite different; I am trying to avoid that error' (See Recollections of 


\section{Laurence Goldstein}

literary style ideal for Wittgenstein's own philosophical purposes had been employed by earlier writers, or that the numbering system of the Tractatus is not without precedent, but such observations do not rate as significant criticisms of the author. The real question to be asked is whether its content marks the text as a defining moment in the history of philosophy.

In one of his early notebooks, Wittgenstein said that his 'whole task' consisted of explaining the nature of the proposition (Satz) $(N$, 39 , entry dated 22.1.15), and, before deciding to adopt Moore's suggestion for a fancy title, he had proposed calling the Tractatus simply Der Satz. ${ }^{7}$ It is a correct theory of propositions, he told Russell, that holds the key to a correct theory of judgment (letter dated 22.7.13, $L R K M, 24)^{8}$. The question of the nature of propositions is, of course, an old one. It had much exercised mediaeval writers, ${ }^{9}$ and

${ }^{7}$ W. W. Bartley III obtained this information from some ex-colleagues of Wittgenstein's who had seen his own copy of the MS at the time when he was working as a village schoolteacher in Semmering. See W. W. Bartley III, Wittgenstein (London: Quartet Books, 1973), 28, fn.2.

${ }^{8}$ Russell seems to have taken this criticism to heart. He wrote a paper of his own, 'On Propositions: What they are and how they mean' (Aristotelian Society Supp. Vol. 2 (1919), 1-43), and, 'paralysed' by Wittgenstein's criticism of his theory of judgment, never published the MS of over 350pp. in which he had developed the theory. See K. Blackwell, 'The Early Wittgenstein and the Middle Russell' in I. Block (ed.), Perspectives on the Philosophy of Wittgenstein (Oxford: Blackwell, 1981), 1-30.

${ }^{9}$ See G. Nuchelmans, Theories of the Proposition: Ancient and Medieval Conceptions of the Bearers of Truth and Falsity (Amsterdam: NorthHolland Linguistic Series 8, 1973).

Wittgenstein, R. Rhees (ed.) (Oxford: Oxford University Press, 1984), 159.) This puts a crimp in - or, more accurately, explodes-the 'resolute reading', for what could that 'further exposition' have amounted to other than the filling in of the arguments sustaining the Tractarian propositions? Resolutists are quite correct to point out that, according to $T, 6.54$, the propositions of the Tractatus (with the exception of 'frame' propositions like 6.54 itself) are, by Wittgenstein's lights, nonsensical. But they are wrong to suppose that there cannot be illuminating nonsense; and further exposition can intensify the illumination. For comparison, according to the late Wittgenstein, (a) 'The square root of $2=m / n$, where ' $m$ ' and ' $n$ ' are integers' is as much nonsense as 'This triangle has four sides'. Yet (a) can be used in a proof that provides a reductio of itself. So (a) is useful nonsense. And this is exactly the status of Tractarian propositions. They are useful in that, by using them (together, preferably, with some further exposition) one can come to see the world aright and pari passu to recognize their nonsensicality. 


\section{How Original a Work is the Tractatus Logico-Philosophicus?}

is prominent in the works of $18^{\text {th }}$ and $19^{\text {th }}$ century authors such as Bolzano, Brentano and Husserl. Propositions are the instruments of verbal communication, and studying how these instruments work, investigating, for example, how a proposition differs from a grammatical string of words, appears to be a challenging project. We cannot be sure why Wittgenstein, in his philosophical noviciate, chose to fasten onto the question of what propositions are-whether reading some particular author fired his interest in the question or planted the seeds of his own ideas. But since, as we shall see, many Bolzanian ideas appear in the Tractatus, it would be interesting to see what Bolzano has to say on this subject.

The first section of Part I, Book One of Bolzano's Wissenschaftslehre $(W L)^{10}$ is on propositions, and Part II of Book Two is devoted to 'Propositions in Themselves'. At the beginning of Part I, §19, Bolzano says

I want to define first what I mean by a spoken proposition or a proposition which is expressed in words. With this name I wish to designate any speech act, if through it anything is asserted or expressed. That is to say, whenever it is one of the two, either true or false in the usual sense of these words'.

So far, so Aristotle. ${ }^{11}$ Bolzano continues:

I call the following sequence of words a spoken proposition: 'God is omnipresent'. For through these words something is asserted; in this case something true. But I also call the following sequence of words a proposition: 'Squares are round'. For through this form of words something is also stated or asserted, although something false and incorrect. On the other hand, I do not call the following expressions propositions: 'The omnipresent God', 'A round square'. For through these expressions something is indeed represented but nothing is stated or asserted. Consequently one can, strictly speaking, neither say that there is anything true, nor that there is anything false in them. Given that it is understood what I mean by a spoken proposition, I should like to note that there are also propositions which are not presented in words but which somebody merely thinks, and these I call mental propositions. Obviously, in the expression 'spoken proposition', I

${ }^{10}$ A partial translation of this work into English is Theory of Science, R.George (ed.) (Oxford: Blackwell, 1972). Subsequent page references will be to this edition.

${ }^{11}$ See Bolzano, $W L \S 23$, p. 27-but Bolzano thinks that Aristotle commits a fallacy if he regards 'A proposition is what is either true or false' as a definition of a proposition. 


\section{Laurence Goldstein}

differentiate the proposition itself from its articulation. In the same way I differentiate a proposition from the thought of it in the expression “mental proposition”.' (WL, \$19, p. 20).

A spoken (or written) proposition is what Wittgenstein calls a 'Satzzeichen'; Bolzano's 'mental proposition' is Wittgenstein's 'Gedanke' (a term also used by Bolzano as a synonym for 'mental proposition' at $W L \S 23$, p. 27 ), which, as they are physical mental existents, have physical constituents. ${ }^{12}$ If we have mental and spoken propositions, what is a proposition in itself (Satz an sich)? Bolzano says that it is 'any assertion that something is or is not the case, regardless whether or not somebody has put it into words, and regardless even whether or not it has been thought' (WL, $\$ 19$, pp. 20-1; also §122). For brevity's sake, Bolzano calls this a 'Satz'. By contrast, a Satz, for Wittgenstein is a symbol that has a perceptible aspect $(T, 3.1,3.11,3.12,3.31,3.32)$, so what seems to be a Platonistic element in Bolzano's scheme is absent in Wittgenstein's. The distinction that Bolzano makes between propositions and expressions that stand for complexes is exactly the one that Wittgenstein brings to bear in his very early (September, 1913) criticism of Frege and Russell: "Frege said "propositions are names"; Russell said "propositions correspond to complexes". Both are false; and especially false is the statement "propositions are names of complexes" $(N, 93)$. It seems not implausible that, in making this criticism, Wittgenstein was drawing on Bolzano's careful discussion. It is also interesting that Wittgenstein's first contribution to philosophy, appears to have been a proposed solution to Russell's Paradox contained in a letter to Philip Jourdain. Like Hieronymous Savonarola, whose solution to the Liar paradox is discussed in a long note attached to $W L, \S 19$, pp. $22-3$, Jourdain, in his reply to Wittgenstein, takes the cassatio line, that paradoxical sentences are 'meaningless limiting cases of statements which are not meaningless' ${ }^{13}$ The idea that contradictions and tautology are limiting cases of propositions, sinnlos but not unsinnig, occurs at $T, 5.143$.

J. N. Findlay claims that

[t]he doctrine of objective propositions had its origins in the Stoic doctrine of $\lambda \epsilon \kappa \tau \alpha$ or things said, and in the doctrine of

Sätze an sich, or propositions-in-themselves of Bernhard Bolzano

${ }^{12}$ In response to a query from Russell, Wittgenstein says 'I don't know what the constituents of a thought are but I know that it must have such constituents' (LRKM, letter from Cassino dated 19.8.19).

${ }^{13}$ See L. Goldstein, Clear and Queer Thinking: Wittgenstein's Development and his Relevance to Modern Thought (London: Duckworth, 1999), 126-7. 


\section{How Original a Work is the Tractatus Logico-Philosophicus?}

in the early nineteenth century. Meinong was undoubtedly the philosopher who gave greatest emphasis to this doctrine of objective propositions and facts, and from him it passed on to Russell and Moore, and thence on to the Wittgenstein of the Tractatus. ${ }^{14}$

Clearly Findlay is right about the similarity of Bolzano's doctrine to Wittgenstein's, but he gives no evidence that any influence of Bolzano or Brentano was mediated by Russell and Moore. Viktor Kraft reports that, according to O. Kraus, Wittgenstein's inspiration for his early views on the relation between language and logic came from Brentano's and Marty's philosophy of language. ${ }^{15}$ It would be fair to say that, in his early work, Wittgenstein performed a useful synthesis. He brought to bear on Russell's great project of handling philosophical problems with mathematical exactitude ${ }^{16}$ the sophistication of a European tradition in the philosophy of language in which he was thoroughly steeped. ${ }^{17}$

${ }^{14}$ J. N. Findlay, Wittgenstein: A Critique (London: Routledge and Kegan Paul, 1984), 31-2. In Chapter 2 of this work, Findlay sketches the relevance, whether direct or indirect, to Wittgenstein's thinking of the 'intentionalists' Brentano, Meinong and Husserl. Findlay remarks that Wittgenstein 'seems to have glanced at some of the earlier works of Husserl on the coffee-tables of Vienna and once asked me, in regard to Husserl's Logical Investigations, why I concerned myself with "that old work"'. Findlay claims that the intentionalists "had ... a great influence on Russell and Moore, and many of their opinions filtered through to Wittgenstein from these and other Cambridge sources' (p. 22).

${ }^{15} \mathrm{~V}$. Kraft, The Vienna Circle: The Origin of Neo-Positivism (New York: Greenwood Press, 1969), 199. (Original German edition published 1953.) I am grateful to Wolfe Mays for pointing me in the direction of this line of thought.

${ }^{16}$ See Russell's letter to Lady Ottoline Morrell dated 29.12.1912. The Russell-Morrell correspondence is housed in the Humanities Research Center, University of Texas.

${ }^{17}$ Hans Sluga mentions the 'profound and lasting effect' that Frege and Russell had on Wittgenstein. 'That influence', he says, 'is particularly noticeable in the Tractatus, which can be read as an attempt to reconcile Russell's atomism with Frege's apriorism'. Sluga also notes that, while he was serving as a soldier in World War I, Wittgenstein renewed his interest in Schopenhauer's metaphysical ethical, aesthetic and mystical outlook expressed in The World as Will and Representation. 'The resulting confluence of ideas', says Sluga, 'is evident in the Tractatus Logico-Philosophicus and gives the book its peculiar character. Fritz Mauthner, the author of Beiträge zu einer Kritik der Sprache (1901-02), who is mentioned at T, 4.0031 , is nominated by Sluga as a likely source of Wittgenstein's view that philosophical problems can be resolved by paying attention to the working of language. Sluga writes 'Wittgenstein's affinity to Mauthner is, indeed, 


\section{Laurence Goldstein}

Georg Henrik von Wright notes that a 'definition of probability which in all essentials answers to Wittgenstein's had been proposed nearly a century earlier by Bolzano' and goes so far as to say that it 'seems appropriate to speak of one definition of probability here and call it the Bolzano-Wittgenstein definition'. Yet von Wright writes 'I doubt that Wittgenstein had ever read Bolzano or even heard of his views of probability' ${ }^{18}$ Von Wright offers no evidence to support this conjecture, and he does not discuss the possibility of an indirect influence. ${ }^{19}$ It is true that Bolzano is not mentioned on a list of people who, in a pocket notebook entry for 1931, Wittgenstein said had influenced him in a particular way, ${ }^{20}$ but there is no reason to think that the list was intended to be exhaustive, and, besides, it is likely (see Jan Sebestik's Appendix to this paper) that Wittgenstein got his Bolzanian ideas via a text book of Robert Zimmermann's, without realizing that they were originally Bolzano's. It is not in the least surprising that a relatively minor character such as Zimmermann should not have made it to Wittgenstein's list of stellar intellectuals who had invented lines of thinking that he passionately took up for his own work of clarification.

Wittgenstein's opinion about his originality is rather difficult to discern. Near the beginning of a long notebook entry for 1931, he says ' $I$ think there is some truth in my idea that I am really only reproductive in my thinking. I think I have never invented a line of thinking but that it was always provided for me by someone else', yet, at the end of that very same entry, he says, 'Anyway, when I was in Norway during the year 1913-14 I had some thoughts of my own, or so at least it seems to me now. I mean that I have the

18 G. H. von Wright, Wittgenstein (Minneapolis: University of Minnesota Press), 144-5.

${ }^{19}$ For documentation on the possible Bolzano influence, see J. Sebestik 'The Archeology of the Tractatus: Bolzano and Wittgenstein', in R. Haller and J. Brandl (eds), Wittgenstein-Towards a Re-Evaluation (Vienna: Verlag Hölder-Pichler-Tempsky, 1989), 112-8. Kraft (op. cit., 153) mentions the theories of probability of von Kries as well as of Bolzano as being precursors of the Wittgensteinian theory.

${ }^{20} C V, 16$. The editors of $C V$ note (p. 101) that the names of Frege, Russell, Spengler and Sraffa were on the original list; Wittgenstein later added the names of Bolzmann, Hertz, Schopenhauer, Kraus, Loos and Weininger.

evident in all phases of his philosophical development, though it is particularly noticeable in his later thinking.' See Sluga's entry on Wittgenstein in R. Audi (ed.), The Cambridge Dictionary of Philosophy (Second Edition) (Cambridge: Cambridge University Press, 1999), 976-80. 


\section{How Original a Work is the Tractatus Logico-Philosophicus?}

impression of having given birth to new lines of thinking at that time'. $(C V, 16-7) .{ }^{21}$ If this is not flatly contradictory, it comes mighty close. In a characteristically fertile metaphor, Wittgenstein once compared himself to some unusual soil which, when sewn with other people's seeds, would enable those seeds to grow in ways different from how they would grow in any other soil $(C V, 42)$. This, I think, is true of his early work. One discovers the inspiration for most of his ideas in the work of other people, so perhaps the Tractatus does not quite merit a place in the pantheon of the greatest, most original works in philosophy.

That, at any rate, was an issue that I raised in a somewhat playful way, in a play published a few years ago called 'Wittgenstein's Ph.D. Viva-a Re-Creation'. ${ }^{22}$ In 1929, Wittgenstein submitted the Tractatus, by then regarded as a classic, as a doctoral dissertation. The viva, conducted by Russell and Moore, was a purely nominal affair, and lasted just a few minutes. My idea was to re-run the viva, with Wittgenstein getting a proper grilling on his text. In this recreation, Russell and Moore criticize Wittgenstein's arguments for some of the main theses of the book and question him rather searchingly on the provenance of some of his ideas. In a footnote commentary at the end of the play, I say:

It is my serious contention that, had Wittgenstein's contemporaries not been so overawed by his personality, and had the dissertation been judged by normal standards of originality and quality of philosophical argumentation, it would have failed. Wittgenstein was, in his twenties [and] philosophically wet behind the ears (although he had produced some interesting ideas in logic)' (WPhD, 513).

In a reply to my play, Michael Cohen takes me to task for accusing Wittgenstein of plagiarism and for distorting the views on Wittgenstein's originality expressed by two other commentators. ${ }^{23}$

${ }^{21}$ This notebook entry for 1931 presents a particularly acute problem for 'resolute' readers of the Tractatus. For they concede that, in his preTractatus writings, Wittgenstein propounded theories of his own (such as the theory of logical portrayal- $N$, p. 15) and endorsed theories of others (such as Russell's Theory of Descriptions) but that by the time of the Tractatus he had come upon the hugely original idea that philosophy is therapy, and that there are no philosophical theories

${ }^{22}$ L. Goldstein, 'Wittgenstein's Ph.D. Viva-A Re-Creation', Philosophy 74 (1999), pp. 499-513; henceforth 'WPhD'. $451-9$.

${ }^{23}$ M. Cohen, 'Was Wittgenstein a Plagiarist?', Philosophy 76 (2001), 


\section{Laurence Goldstein}

Cohen's complaints are generally poorly founded, for his paper rests on a series of mistakes. The first of these mistakes involves a confusion between fact and fiction. In my play, there are fictional counterparts of the examiners, and of Wittgenstein. I shall call these FicRussell, FicMoore and FicWittgenstein respectively. ${ }^{24}$ FicRussell and FicMoore say and do much in the play that their real world counterparts did not do. In particular, they subject FicWittgenstein to a tough and sometimes fairly aggressive Ph.D. viva, and end up failing him. FicWittgenstein replies to their substantive questions in the way I imagine Wittgenstein would have done, and his replies are generally unsatisfactory. (I recognize, of course, that many readers of the play will think that the criticisms made by FicRussell and FicMoore are not as decisive as I took them to be, and will think that Wittgenstein would have put up a more solid defence.)

Now, at one point in the play, FicRussell says to FicWittgenstein: 'You must admire [Bolzano] ... judging by the extent to which you have plagiarized his writings. Cohen fastens onto the word 'plagiarize', retails a definition of it that he found in his Oxford English Reference Dictionary and uses the word in the arresting title of his piece 'Was Wittgenstein a Plagiarist?'. The word, remember, is used by the fictional Russell but, according to Cohen, the accusation would have been made by the real Goldstein who put the words into the mouth of the fictional Russell. Yet what I actually say, speaking in propria persona, (and Cohen quotes this) is '... had the dissertation been judged by normal standards of originality and philosophical argumentation, it would have failed'. When the fictional viva is over and FicWittgenstein has left the room, FicRussell says to FicMoore 'I mentioned Bolzano, but I could easily have mentioned others from whom [FicWittgenstein] has derived ideas without acknowledgment. ... He certainly wouldn't appreciate others plagiarizing from him'. There is no suggestion here that Wittgenstein tried to pass these ideas off as his own. My own dictionary, the Collins English Dictionary (Millenium Edition) ('voted the world's best dictionary') defines 'plagiarize' as 'to appropriate (ideas, passages etc.) from (another work or author)', and defines the verb 'to appropriate' as 'to take for one's own use'-NOT, note 'to take as one's own'. But it is hardly worthwhile discussing such nuances because it is just silly to confuse the views of the fictional Russell with those of his real creator. In my book Clear and Queer Thinking: Wittgenstein's Development and his Relevance to Modern Thought

${ }^{24}$ Cohen uses the scare-quote names “"Russell”" etc., but I wish to avoid the sneering tone thus engendered. 


\section{How Original a Work is the Tractatus Logico-Philosophicus?}

(henceforth $C Q T),{ }^{25}$ speaking of the actual Wittgenstein, I wrote:

Prolonged isolation on the bank of a Norwegian fjord in the years 1913-14, an austere regime of sensuous deprivation and intense concentration when, as he put it, his 'mind was really on fire', produced striking results for Wittgenstein in the field of philosophical logic - the theory of the nature of propositions and of tautologies and contradictions, the doctrine of ineffability, the semantic method for studying logical entailment and much more. But his views in general philosophy remained amazingly naive, perhaps not surprisingly, considering how little he had studied the subject. Some of his subsequent wartime jottings indicate that Wittgenstein was still wetting the bed, philosophically speaking $(C Q T, 80)$.

I give some illustrations of this in the book. Wittgenstein clearly picked up a certain amount of philosophy at home and at school, but he was trained as an engineer and his knowledge of the literature on many of the perennial questions of philosophy was, to put it kindly, somewhat sketchy.

On the question of the charge of plagiarism against Wittgenstein, my book is quite explicit. I note that, as regards material possessions, '[w] hen able to do so, he gave freely to others, and was disgusted when others did not show similar generosity', and I continue:

As with goods and money, so with ideas. These too are to be shared. Hence it really was a matter of indifference to Wittgenstein, as he indicates in the Prefaces to both the Tractatus and the Philosophical Investigations, that he was not the 'owner' or originator of some of the thoughts he published; so he didn't trouble to mention the names of the authors who were. In the world of ideas, he seems to hold, one should be able to take without even having to ask, and to acknowledge would be the height of bad taste $(C Q T, 178)$.

In a footnote to this passage (p. 224), I elaborate:

I have heard Richard Hare remark that the Oxford of his day was a free port for ideas. Academics nowadays, under heavy pressure to publish and to make names for themselves might see a failure to acknowledge intellectual debts as simply dishonest and cheap. Which it is. Yet people feel quite relaxed about retelling, without

${ }^{25}$ L. Goldstein, Clear and Queer Thinking: Wittgenstein's Development and his Relevance to Modern Thought (London: Duckworth, 1999). 


\section{Laurence Goldstein}

acknowledging a source, jokes that are not their own. So perhaps we should not be too hasty to accuse Wittgenstein of plagiarism - perhaps in his time, or in his mind, philosophy was not regarded as private property, but as ideas to be shared and enjoyed.

In my re-creation of Wittgenstein's viva, a number of philosophical theories are discussed. Cohen says that I make 'particular play' of Russell's theory of judgment but, as the reader can verify, that is plain false, for Russell's theory is mentioned once and discussed not at all. Cohen is keen to show that I am ignorant of Wittgenstein's criticism of this theory, and he cites a passage of the Tractatus not mentioned in my viva re-creation, in which this criticism, and Wittgenstein's own position, is set out. But the self-same passage $(T, 5.54-5.5423)$ occupies almost the whole of p. 96 of my book, where it is quoted in full. It is clear that one ought to seek evidence for the claim that there is a similarity between views of Russell and Wittgenstein in passages other than those in which Wittgenstein is expressly repudiating aspects of Russell's theory. One such passage is T, 3-3.5 which, as Anthony Kenny correctly notes, constitutes, together with the notorious 5.54-5.5423, Wittgenstein's analysis of sentences reporting beliefs, judgments, perception and the like. ${ }^{26} \mathrm{It}$ is in the former passage that some of Russell's views are unmistakably evident, although at least one-the theory of types-is rejected $(T, 3.331-3.333)$.

In the Preface to the Tractatus, Wittgenstein writes 'I do not wish to judge how far my efforts coincide with those of other philosophers. Indeed, what I have written here makes no claim to novelty in detail, and the reason why I give no sources is that it is a matter of indifference to me whether the thoughts that I have had have been anticipated by someone else' $(T$, p. 2$)$. Cohen draws attention to this passage, apparently in an effort to show that a charge of plagiarism against Wittgenstein is inapposite. He also makes the point that both English translations miss the emphasis conveyed by the word 'überhaupt' in the original. Correctly translated, Wittgenstein is saying that he 'makes no claim at all to novelty.....'. Now, assuming, reasonably enough, that Wittgenstein was being neither modest nor dishonest, then we must take this disclaimer at face value. It

${ }^{26}$ A. Kenny, 'Wittgenstein's Early Philosophy of Mind' in I. Block (ed.), Perspectives on the Philosophy of Wittgenstein (Oxford: Blackwell, 1981), 140-7. See also the Candlish-Sainsbury symposium in R. Monk and A. Palmer (eds), Bertrand Russell and the Origins of Analytical Philosophy (Bristol: Thoemmes Press, 1996), 103-51, on the relation between the theory of the proposition and the theory of judgment in Russell and Wittgenstein. 


\section{How Original a Work is the Tractatus Logico-Philosophicus?}

would be interesting to learn whether Cohen would have awarded a $\mathrm{Ph}$.D. to a dissertation that self-avowedly made no claim at all to novelty on individual matters and, apart from this blanket acknowledgment and the mention of intellectual debt to two people, cited no sources of borrowed ideas.

Cohen further charges me with misrepresenting the views of Anthony Grayling and Jan Sebestik regarding the influence on Wittgenstein of Russell and Bolzano respectively. It would, again, have been very easy for Cohen to check with these authors whether in fact they wished to distance themselves from views I attributed to them. I checked with both of them; neither did. I shall leave the defence of Sebestik to Sebestik who is currently involved with a long project on both the Bolzano-Wittgenstein concordance and on Bolzano's posthumous reception, but who has contributed an Appendix to the present essay. It might be useful, however, to say a few words about the alleged misrepresentation by me of Grayling, since this will introduce us to three more of Cohen's mistakes. $\mathrm{He}$ cites selectively from Grayling and, on the basis of the bits selected, says that Grayling does not make a claim with which I 'saddle' him, about theses taken by Wittgenstein from Russell. Grayling, in fact, assembles substantial evidence for the claim that certain material in Russell should be regarded as what he calls an 'anticipatory sketch of Wittgenstein's Tractatus' (1996, pp. 99-100); as he elsewhere says, 'the Tractatus owes its existence and many of its ideas to [Russell's The Principles of Mathematics and the Russell/Whitehead Principia Mathematica]' (1988, p. 56).

Grayling cites ten theses from the Tractatus (1, 1.1, 2, 2.01, 2.02, $3,3.1,3.2,4.21,5)$ and remarks: 'It goes without saying that the logical ideas which underlie these theses are of course familiar from earlier work by Russell'. And even more striking, Grayling says, 'is the actual content of the views respectively expressed by Wittgenstein in the Tractatus and Russell in the second chapter of Our Knowledge of the External World', from which Grayling quotes an illustrative passage. ${ }^{27}$ Cohen too cites this passage, but he does so in order to show that Wittgenstein did not copy from Russell! This might seem very curious indeed, until we notice that, at the end of a footnote, Cohen casually remarks 'My selections from this passage are not the same as Grayling's' ${ }^{28}$ And, of course, when one inspects the passage from Our Knowledge of the External World cited by

${ }^{27}$ A. C. Grayling, Russell (Oxford: Oxford University Press, 1996), 99-101, and id, Wittgenstein (Oxford: Oxford University Press, 1988), $56-7$.

${ }^{28}$ Cohen, op. cit., 453, footnote 4. 


\section{Laurence Goldstein}

Grayling in order to ascertain what Cohen has not selected, one finds Russell distinguishing between facts and things, introducing atomic propositions and atomic facts, discussing how these are related and how the analysis of propositions brings us to atomic propositions-an apparatus imported by Wittgenstein into the Tractatus. ${ }^{29}$ It goes without saying that much of Russell's Our Knowledge of the External World is not imported into the Tractatus, and it is easy for Cohen to find bits that are not. That might be thought to be of some significance, only if one confused two things' being similar with two things' being identical.

The next mistake is that of thinking that 'A influences B' entails ' $\mathrm{B}$ did not influence $\mathrm{A}$ '. Cohen cites Russell describing his lectures on logical atomism as 'very largely concerned with explaining certain ideas which I learnt from my friend and former pupil Ludwig Wittgenstein'. This is a generous tribute, since, as Grayling points out 'most of what is essential to Russell's views in the Lectures is already to be found in work published before he met Wittgenstein', ${ }^{30}$ but the beneficiary, arrogant young ingrate that he was, could only

${ }^{29}$ Some sentences in the Russell passage omitted by Cohen: 'When I speak of a "fact", I do not mean one of the simple things in the world; I mean that a certain thing has a certain quality, or that certain things have a certain relation.... Now a fact, in this sense, is never simple, but always has two or more constituents. ... Given any fact, there is a proposition which expresses the fact ... [such a proposition] will be called an atomic proposition, because .... there are other propositions into which atomic propositions enter in a way analogous to that in which atoms enter into molecules... In order to preserve the parallelism in language as regards facts and propositions, we shall give the name "atomic facts" to the facts we have hitherto been considering'. It is important to note, however, as both Erik Stenius and Anthony Palmer have done, that the Ogden translation of 'das Bestehen von Sachverhalten' in $T, 2$ as 'the existence of atomic facts' masks important dissimilarities between Wittgenstein's Sachverhalte and Russell's atomic facts. Palmer's translation 'the holding (or obtaining) of states of affairs' is much to be preferred. See E. Stenius, Wittgenstein's Tractatus: A Critical Exposition of its Main Lines of Thought (Oxford: Blackwell, 1960), p. 31; A. Palmer, 'The Complex Problem and the Theory of Symbolism', in R. Monk and A. Palmer (eds), Bertrand Russell and the Origins of Analytical Philosophy (Bristol: Thoemmes Press, 1996), 155-82.

${ }^{30}$ A. C. Grayling, Wittgenstein (Oxford: Oxford University Press, 1988), p. 57. Writing about his intellectual contact with Wittgenstein prior to the First World War, Russell says: 'Wittgenstein's doctrines influenced me profoundly. I have come to think that on many points I went too far in agreeing with him'. See B. Russell, My Philosophical Development (London: Unwin, 1959), 83. 


\section{How Original a Work is the Tractatus Logico-Philosophicus?}

manage a thinly veiled denigration of Russell in return. In the preface to the Tractatus, he says 'I am indebted to Frege's great works and to the writings of my friend Mr. Bertrand Russell', the implicature of which has also been remarked upon by many others. ${ }^{31}$ Whereas Russell scrupulously pays generous tribute to Wittgenstein, Wittgenstein scrupulously avoids paying generous tribute to Russell. This, of course, does not mean that Wittgenstein was not profoundly influenced by Russell, nor that he did not borrow a number of important ideas from Russell; it means only that he was somewhat lacking in courtesy. There is certainly a lack of courtesy, in Cohen's failure to consider this possibility.

In my play, I have FicRussell accuse FicWittgenstein of helping himself to many of Bolzano's theories-that a proposition has a unique analysis, that all necessity is logical, the theory of logical consequence, the theory of probability, of variable proposition and so on. Cohen says that Sebestik, on whose paper 'The Archeology of the 'Tractatus: Bolzano and Wittgenstein' I drew, is an unreliable guide and he disputes whether Bolzano is a likely source of all these views. $^{32}$ A short response to that charge is contained in the Appendix. For the most part, I find Cohen's objections insubstantial (he points to certain differences between Bolzano's views and Wittgenstein's but-remembering mistake number 4-profound similarity does not entail no differences at all, and, as we have seen, their views on probability are so similar that von Wright refers to 'the Bolzano-Wittgenstein definition'), but I do concede that, for example, the idea for the ' $\mathrm{N}$ ' operator of joint negation in the Tractatus may not have come, contrary to what Sebestik supposes, from Bolzano. I also think that I was wrong in my reading of the

${ }^{31}$ Including P. Simons, 'Frege and Wittgenstein, Truth and Negation' in R. Haller and J. Brandl (eds), Wittgenstein: Towards a Re-evaluation (Vienna: Hölder-Pichler-Tempsky), 119-29. Simons says 'Wittgenstein's personal debt to Russell was of course inestimable, and I would judge his intellectual debt to Russell was also greater than to Frege' (p. 119).

${ }^{32}$ In the article mentioned by Cohen, Sebestik notes that 'another source of Bolzano's influence is perhaps more important. His logical doctrines pervaded Austrian philosophy in an unexpected way, through the intermediary of the first edition of Zimmermann's very influential textbook, which was often imitated...' (p. 117). Cohen goes so far as to claim that Wittgenstein was not a student of Austrian philosophy (p. 456). This is a strange claim to make, especially in light of the fact that, included in a list, cited by Cohen, of those whom Wittgenstein said had influenced his thought $(C V, 16)$ is Ludwig Boltzmann who held the chair for philosophy of the inductive sciences at the University of Vienna from 1902 to 1906. 


\section{Laurence Goldstein}

English version of Wittgenstein's prefatorial disclaimer, 'Indeed what I have written here makes no claim to novelty in detail'. I agree with Cohen that, in the German original, 'im Einzelnen' does not carry the sense of 'in (minor) details', and I would translate it here as 'on individual matters'. While in this confessional mood, I should like to mention a point not picked up by Cohen, but which was drawn to my attention by Warren Goldfarb. Goldfarb said that it had become almost folklore among philosophers that Ramsey's remark 'what we can't say we can't say, and we can't whistle it either' occurs in his review of the Tractatus. I too was guilty of this misperception, and, in footnote 33 (p. 509) of WPhD, I incorrectly cited the review as the source of this remark. In fact, it is to be found in Ramsey's 'General Propositions and Causality', which in the old edition of Foundations is published among the Last Papers (1929). ${ }^{33}$

\section{Sparks from a Mind on Fire}

There is undoubtedly, in the Tractatus, criticism of doctrines of Frege and Russell that is both severe and acute. There are also doctrines of Wittgenstein's own that are novel and are intensely interesting whether or not they are ultimately sustainable. As we have already mentioned, Wittgenstein, in his early period, saw his 'whole task' as that of explaining the nature of the proposition. Evidence suggests that what he regarded as his central contribution to the theory of the proposition was the doctrine of what cannot be said by a proposition, but can only be shown. 'The main point' of the Tractatus, as he explains to Russell, 'is the theory of what can be expressed by propositions-i.e. by language-(and, which comes to the same thing, what can be thought) and which can not be expressed by propositions, but only shown; which, I believe, is the cardinal problem of philosophy' (letter dated 19.8.19, LRKM, 71). ${ }^{34}$ Later

\footnotetext{
${ }^{33}$ R. B. Braithwaite (ed.), F. P. Ramsey: The Foundations of Mathematics (London: Routledge and Kegan Paul, 1931), 238.

${ }^{34}$ Note the date of this letter. Certain 'resolutists' claim that, although in his early notebooks, Wittgenstein may have spoken of theories, by the time of the composition of the Tractatus he had arrived at the view, set out unequivocally in his later writings, that philosophy does not consist of theories, but rather offers a certain type of therapy. This letter to Russell, however, was written after the completion of the Tractatus. The 'resolutist' claim that the Tractatus only pretends to offer theories when really it is just exposing the pretensions of philosophical theorising, is, anyway, utterly silly. For, if that had been Wittgenstein's intent, he would surely 


\section{How Original a Work is the Tractatus Logico-Philosophicus?}

in this letter, he again refers to 'the cardinal question of what can be expressed by a prop[osition], and what can't be expressed, but only shown' (LRKM, 72). The rôle of the theory of showing in Wittgenstein's early period writings may be compared with that of the theory of Forms in Plato. Both authors thought that they had discovered a powerful explanatory device that could be brought to bear on a wide and diverse range of recalcitrant problems. For Wittgenstein, showing, apart from being the key to the little semantical matter of elucidating the relation of words to the world, ${ }^{35}$ also plays a major rôle in logic (the theory of inference- $T, 5.13-5.132$ ), in the theory of internal properties and relations $(T, 4.12-4.1241)$, of formal concepts $(T, 4.126-4.1274)$, provides the key to the problem of how much truth there is in solipsism $(T, 5.62)$ and even unlocks the mysteries of ethics, to the extent of demonstrating why they cannot be unlocked but must remain forever in the realm of the mystical. ${ }^{36}$

The remark 'What can be shewn cannot be said' ( $T, 4.1212)$ appears verbatim in an entry dated 29.11.14 in Wittgenstein's notebook $(N, 34)$ but earlier that year, when Moore visited him in Skjolden, a revelation about showing was the first thing he got Moore to note down: 'Logical so-called propositions shew [the] logical properties of language and therefore of [the] Universe, but say nothing' (April, 1914, N, 107). This sentence encapsulates two of the most important novel doctrines of Wittgenstein's early period. The first is, of course, the aforementioned doctrine of showing. Ordinary propositions show what they say; tautologies and contradictions show that they say nothing $(T, 4.461)$.

The second doctrine concerns the nature of logic. Wittgenstein is here careful to call tautologies 'so-called propositions', because his theory requires that both tautologies and contradictions are not

${ }^{35}$ 'Elucidating', not 'explaining' since, on Wittgenstein's view, there is no explaining, or putting into words, the relation between words and world. A philosophical work, he says, consists essentially of elucidations $(T, 4.112)$, and his are, strictly speaking, nonsensical (unsinnig) - beyond the bounds of the understanding $(T, 6.54)$.

${ }^{36} T$ 6.522: 'There are things that cannot be put into words. This makes itself manifest, it is the mystical. What Pears/McGuinness translate 'make manifest' is 'zeigen' (translated 'shows' in Ogden/Ramsey). T 6.421: 'It is clear that ethics cannot be put into words'.

have made it clear to Russell or to Ramsey or to any of the other clever people with whom he discussed the text at length that this was indeed what he was about. 


\section{Laurence Goldstein}

Sätze, for they say nothing ( $T, 6.11)$. Logical so-called propositions are pseudo-propositions (Scheinsätze). 'Pseudo-propositions are such as, when analysed, turn out after all only to shew what they were supposed to say' $(N, 16)$. Although in the Tractatus he sometimes talks of 'logical propositions', it is clear that these logical propositions are as much propositions as a rocking horse is a genuine horse. Ramsey, in accepting the 'profound analysis' given by Wittgenstein, distinguishes tautologies and contradictions from what he calls 'genuine propositions' - what Wittgenstein had called 'real propositions' $(N, 107) .{ }^{37}$ In a very early letter to Russell (dated 22.6.12) Wittgenstein had announced that '[1] ogic must turn out to be of a TOTALLY different kind than any other science' (LRKM, 10). Five or six months later, in a letter from his retreat in Skjolden, he is able to announce as 'definitive' the claim that '[a]ll the propositions of logic are generalizations of tautologies and all generalizations of tautologies are propositions of logic. There are no other logical propositions' $(L R K M, 41)$. His striking new vision-that logic is not an assembly of general truths, but consists of tautologies lacking sense (sinnlos) was also accepted by, inter alia, Russell and Carnap. ${ }^{38}$

Why these two doctrines are particularly important, and what problems they were initially designed to solve is a matter of some controversy. The answer to the latter question is, in my view, the tortoise and the horse respectively. The thesis that valid inferences are shown in tautologies and do not need any additional justification neatly stops the infinite regress into which Lewis Carroll's tortoise led Achilles. ${ }^{39}$ And the doctrine of showing is supposed to free us from Frege's problem about the concept horse not being a concept. What manner of logical beast a horse is is shown in sentences relating to horses-we do not need, nor can we have, non-nonsensical sentences which say what is thus shown about the concept of a horse. ${ }^{40}$

${ }^{37}$ Ramsey 'The Foundations of Mathematics' (1925) in D. H. Mellor (ed.), Foundations: Essays in Philosophy, Logic, Mathematics and Economics (London: Routledge and Kegan Paul, 1978), 210-11.

${ }^{38}$ Russell writes: 'Wittgenstein maintains that logic consists wholly of tautologies. I think he is right in this, although I did not think so until I had read what he had to say on the subject'. See My Philosophical Development (London: Unwin, 1959), 88. For Carnap, see his 'Autobiography' in P. A. Schilpp (ed.) The Philosophy of Rudolph Carnap (La Salle: Open Court, 1963), 27, quoted in WPhD, 502, footnote 15.

${ }^{39}$ L. Carroll, 'What the tortoise said to Achilles', Mind 4 (1895), 278-80. Wittgenstein's argument is set out at $T, 6.1221$ and, in a somewhat more clear and expanded form, at $N, 107-8,111$.

${ }^{40}$ See my $C Q T, 18-19$. 


\section{How Original a Work is the Tractatus Logico-Philosophicus?}

Apart from these two doctrines, Wittgenstein's account of numbers as exponents of operations $(T$ 6-6.022) is, I believe, entirely novel.

\section{Finding his own voice}

After retiring from Philosophy, and either causing or being the victim of uproar in a six year period as a teacher in some schools in rural Austria, ${ }^{41}$ Wittgenstein returned to Vienna when, among other things, he built a house for his sister and was lionized by the Vienna Circle. Some members of the Circle encouraged him to attend a lecture delivered by Brouwer in Vienna, in March, 1928, and this event was apparently of major significance in revitalizing his interest in philosophy and marks the beginning of his so-called 'transitional period'. It has to be said that, in the MSS surviving from this period, there is a great deal of material that is of poor quality. ${ }^{42} \mathrm{It}$ is worth drawing attention to this material because what we see in these manuscript notebooks is Wittgenstein struggling, and it is perfectly clear that, unlike Mozart from whose pen perfectly formed symphonies were said to flow, Wittgenstein had to graft-to abandon poor ideas, and to constantly revise and rework. He says as much in the Preface to $P I$ : 'The same, or almost the same points were always being approached afresh from different directions, and new sketches made. Countless of these were badly drawn or uncharacteristic, marked by all the defects of a weak draughtsman. And when they were rejected a number of tolerable ones were left....'

One finds, in both his own transitional MSS and in the recordings made by Waismann of Wittgenstein's discussions with the Vienna Circle ( $W V C)$, that, from 1929 and into the early 1930's

${ }^{41}$ The usual story is that Wittgenstein's temper and violent behaviour got him into trouble. W. W. Bartley III, in his Wittgenstein (London: Quartet Books, 1973), 62-94, tells a different tale in which Wittgenstein is the victim of the evil machinations of some sad, small-minded, devious, malevolent individuals. Such a case is described in Philip Roth's novel, The Human Stain (London: Vintage, 2000) but, of course, one does not need to resort to fiction for more examples of smear campaigns against teachers, and I believe that Bartley's account should be taken very seriously.

${ }^{42}$ I am grateful to the Wittgenstein Archive in Bergen, Norway, for granting me access to this material and for the use of their search engine while it was under development. All of the MSS have now been transcribed and published as a set of CD-ROMs, The Wittgenstein Nachla $\beta$ (Oxford: Oxford University Press, 1999). 


\section{Laurence Goldstein}

Wittgenstein was working to repair cracks that he perceived in the Tractatus. His paper 'Some Remarks on Logical Form' $(R L F)$, dating from that same year as his viva, was largely a presentation of Tractarian ideas. We see problems such as colour exclusion-the prima facie non-independence of elementary colour-ascribing propositions-exercising him in the early 1930's $(P R)$, and he devised some short-lived theories to deal with them.

During this transitional period, Wittgenstein delivered a public lecture on ethics, of which we have a published text, $L E$. Admittedly this lecture was for a lay audience and so perhaps was not intended to be too philosophically taxing, but even so, given previous announcements he had made about the deep importance of ethics, and about the Tractatus being, surface appearances to the contrary, an ethical work, one might have expected some fireworks. But the 'Lecture on Ethics' is a damp squib. Wittgenstein makes the familiar distinction between categorical and hypothetical judgments, and he draws attention to the difference between behaviour as naturalistically described and as normatively described, but there is virtually nothing in that lecture that has had an effect, let alone a lasting effect, on subsequent moral thinking. ${ }^{43}$

In the preface to the Philosophical Investigations, Wittgenstein wrote:

Four years ago I had occasion to re-read my first book (the Tractatus Logico-Philosophicus) and to explain its ideas to someone. It suddenly seemed to me that I should publish those old thoughts and the new ones together: that the latter could be seen in the right light only by contrast with and against the background of my old way of thinking ( $P I$, viii)

Evidently he himself was conscious of thinking in a new way. In the late MSS, whenever he refers to his earlier work or to its author, Wittgenstein almost invariably seeks to distance himself from, and not to associate himself with it or him.

His new way of thinking was indeed a whole new way of thinking, and some of its contours are known from Wittgenstein's explicit assertions. Philosophical confusion, he now believes, springs from our bewitchment by language (PI, § 109). The remedy is to

${ }^{43}$ Rupert Read has argued that, in a better world, writers on ethics would have been more strongly influenced by Wittgenstein-would have been more courageous in abandoning moral theory. See his 'Review of R. Hursthouse, On Virtue Ethics', Philosophical Investigations 24 (2001), $274-82$. 


\section{How Original a Work is the Tractatus Logico-Philosophicus?}

scrutinize carefully the way that words are misused in particular philosophical utterances, and to remind ourselves ${ }^{44}$ of the subtle differences ${ }^{45}$ between ways in which those words, in normal, everyday use, are used. ${ }^{46}$ 'If I had to say', he says, 'what is the main mistake made by philosophers of the present generation, including Moore, I would say that it is that when language is looked at, what is looked at is a form of words and not the use made of the form of words' $(L A, 2)$. Close attention to particularities of use is the complete antithesis of the theory-building that he had formerly regarded as paradigmatic of philosophy, and it scarcely needs arguing that, by this stage, Wittgenstein was speaking in a highly original way. His philosophy of mathematics, which occupied a large proportion of his time up to 1944 is also distinctive. Distinctively mad, some would say, an outrage to good sense and born of ignorance of the subject beyond an elementary level. However, this latter criticism, which used to be common, has now been brought into question by some very interesting research on the background to some of his remarks on set theory and on Gödel's Theorem. ${ }^{47}$

The view I have been defending in this paper is that, early on, Wittgenstein was a derivative thinker, that the confession he made about his own lack of originality was well founded. The Tractatus is an important work, but it is the fruit of seeds sown in Wittgenstein's soil by Frege, Russell and many others. Then a wonderful transformation occurred both in his character and in his philosophy, when Wittgenstein discovered his unique philosophical voice. ${ }^{48}$

${ }^{44}$ 'The work of the philosopher consists in assembling reminders for a particular purpose' $P I \$ 127$; see also $\$ 89$.

${ }^{45}$ According to M. O'C. Drury, Wittgenstein once contemplated using as a motto for PI a quotation from King Lear: 'I'll teach you differences'. See K. T. Fann (ed.), Ludwig Wittgenstein: The Man and his Philosophy (New York: Dell, 1967), 69.

${ }^{46}$ At $P I \S 116$, Wittgenstein describes his enterprise as bringing words back from their metaphysical to their everyday use. $\$ \S 114-116$ is a critique of the claim made at $T 4.5$, that the general form of a proposition is 'This is how things are'.

${ }^{47}$ V. Rodych, 'Wittgenstein's Critique of Set Theory', The Southern Fournal of Philosophy 38 (2000), 281-319; J. Floyd and H. Putnam, 'A Note on Wittgenstein's “Notorious Paragraph” about the Gödel Theorem', The Fournal of Philosophy 97 (2000), 624-632; C. Sayward, 'On Some Much Maligned Remarks of Wittgenstein on Gödel', Philosophical Investigations 24 (2000), 262-70.

${ }^{48}$ The Hintikkas see it as a slow transition culminating in the notion of a language-game occupying centre-stage in Wittgenstein's thought. See M. B. and J. Hintikka, Investigating Wittgenstein (Oxford: Blackwell, 1986), 190. 


\section{Laurence Goldstein}

Wittgenstein admitted the limitations of his talent, ${ }^{49}$ but he drove himself hard, was remorselessly self-critical, and became both a better man and a more original philosopher. ${ }^{50}$ The footnote from WPhD already quoted continues:

Subsequently, after many years of struggle against his personal vices and against the naive preconceptions that informed the Tractatus, he went on to produce truly great and highly original thought. I concur with Michael Dummett in his judgment that 'No one capable of recognizing profound philosophy can open the Philosophical Investigations without perceiving that it is a work of genius'. ${ }^{51}$

\section{Appendix by Jan Sebestik}

After the death of Bolzano, there were several allegations concerning the plagiarising of his ideas. Robert Zimmermann, the author of the Philosophische Propädeutik (1st ed. 1853) was one of the accused. The accusers were right, although it is the case that Bolzano wanted his ideas to be propagated without his name being mentioned. In Austria, Bolzano was at that time still persona non grata and a public profession in favour of him would likely have met with official reprobation that could have harmed Zimmermann's university

${ }^{49}$ Though this occurs in one of his more stupid remarks: 'Even the greatest Jewish thinker is no more than talented. (Myself for instance.)' $(C V, 16)$.

${ }^{50}$ After writing this paragraph, I glanced at Georg von Wright's biographical sketch of Wittgenstein, and was happy to find that, on this issue, my views and von Wright's pretty well coincide. According to von Wright '[I]t was above all Sraffa's acute and forceful criticism that compelled Wittgenstein to abandon his earlier views and set out upon new roads. He said that his discussions with Sraffa made him feel like a tree from which all branches had been cut. That this tree could become green again was due to its own vitality. The later Wittgenstein did not receive an inspiration from outside like that which the earlier Wittgenstein obtained from Frege and Russell'. See G. H. von Wright, Wittgenstein (Minneapolis, University of Minnesota Press, 1982), 28. In a footnote (15, p. 27), von Wright remarks 'The Tractatus belongs in a definite tradition in European philosophy, extending back beyond Frege and Russell at least to Leibniz. Wittgenstein's so-called "later philosophy", as I see it, is quite different. Its spirit is unlike anything I know in Western thought and in many ways opposed to aims and methods in traditional philosophy'.

${ }^{51}$ M. Dummett, Origins of Analytical Philosophy (London: Duckworth, 1993), p. 166. 


\section{How Original a Work is the Tractatus Logico-Philosophicus?}

career. This is why Zimmermann abandoned almost all Bolzanian ideas in the second edition of his textbook (1860), a rare case in philosophical literature when the second edition is definitely worse than the first. ${ }^{52}$ Misadventure befell Husserl after his enthusiastic pronouncement in favour of Bolzano in the Logical Investigations. In Der Streit der Psychologisten und Formalisten in der modernen Logik (1902), Melchior Palágyi warned of a 'formalistic danger'. According to Palágyi the 'true originator' of the 'formalistic tendency in modern logic' had been Bolzano whose successor was Husserl in the Logical Investigations. In a review of Palágyi's book, Husserl writes :

Here I must first mention the suggestive manner in which Palágyi conceives of my relations with Bolzano. In a series of hints which would be insignificant taken separately, but which are effective when taken in sequence, he gives the reader no less a notion than that I have exploited Bolzano in a dishonest manner and have kept silent about my dependence upon him. Suppressing judgment on the author's procedure, I note, for the benefit of the uninformed, that not only-as the author once mentions (p. 16)have I 'remembered' Bolzano and 'named' him one of the greatest of logicians. Rather-in an 'Appendix' to chapter 10 of Logische Untersuchungen, Vol. 1, an appendix specifically devoted to this purpose-I have pointed out the significance of the Wissenschaftslehre as one of the foundation works of logic, and have stressed the necessity of building upon this work and of studying it with the greatest care. This I have done in such a detailed manner, and with such emphasis as never before, either in earlier times or contemporary. And, not satisfied with that, I expressly designated Bolzano as the one (along with Lotze) by whom I have been 'decisively influenced.' These words I quote from Logische Untersuchungen, Vol. 1, 226 (1st ed.). ${ }^{53}$

Similar remarks can be found in the Preface to the second edition of Logical Investigations and in Ideen zu einer reinen Phänomenologie und phänomenologischen Philosophie (1913), book III, §10.

${ }^{52}$ On all these matters, see E. Morscher, 'Robert Zimmermann-der Vermittler von Bolzano's Gut? Zerstörung einer Legende', in H. Ganthaler and O. Neumaier (eds), Bolzano und die österreichische Geistesgeschichte (Sankt Augustin: Academia, 1997), 145-236.

${ }^{53}$ Husserliana XII (The Hague: Nijhoff, 1970), 287-94. (Husserl's review appeared in 1903); English translation by D. Willard, in J. N. Mohanty (ed.), Readings on Edmund Husserl's Logical Investigations (The Hague: Nijhoff, 1977), 36. 


\section{Laurence Goldstein}

Wittgenstein did not consider his early work original and he did not care about citing his sources. I do not know whether he consulted the Wissenschaftslehre. For me, his most probable source, direct or indirect, of Bolzanian ideas is Zimmermann's Propädeutik. There, Zimmermann explains the most important logical theories of Bolzano without mentioning Bolzano's name in connection with them. In fact, he mentions him three times, but in relation to minor points, in order to hide the fact that he borrowed his important ideas. So, without being aware of their provenance, Wittgenstein could have taken from an old textbook Bolzano's method of variation, his concept of logical consequence (WL II, §155) and his diagnosis of the link between consequence and probability (WL II, $\S \S 161,162)$. These doctrines were widely known in Austria at the time, and were taught at secondary school level. Zimmermann acquired Bolzano's mathematical Nachla $\beta$ which he lent to the Academy of Science in Vienna in 1882 and gave to the Hofbibliothek in 1892, probably without having looked at it. He did not plagiarise the Nachla $\beta$, but the Wissenschaftslehre.

If Cohen is making the uncontested claim that Wittgenstein was not a university student of Austrian philosophy, then this is, of course, correct. But Wittgenstein spent the first seventeen years of his life in Austria, in a very sophisticated milieu, where art, literature, music and also philosophical conversation were vigorously prosecuted in the family home. He often returned to Austria and he knew probably more about Austrian philosophy than has so far been recognized. But much about his intellectual development remains unknown. Did he ever look at Husserl's Logical Investigations in his younger years? And did he come into contact abroad with people who, like Russell, were somewhat familiar with Austrian philosophy?

For reasons adumbrated above, I deliberately quoted Zimmermann on the 'method of variation' rather than Bolzano, although Zimmermann's illustration of the method is not a good one (Bolzano, too, has it, but he also has better examples). According to Cohen, concerning the method of variation, I should have quoted Russell's remarks in The Principles of Mathematics on transforming constants into variables. However, Russell, writing on variables in The Principles, refers to a formal language while Bolzano explains his conception for natural languages. When Russell transforms a constant into a variable, he in fact substitutes the variable for the constant and instead of ' $\varphi(\mathrm{a})$ ', he writes ' $\varphi(\mathrm{x})$ '. This is not at all what Bolzano (and Zimmermann) had in mind. Bolzano does not substitute a variable for the constant, he simply 


\section{How Original a Work is the Tractatus Logico-Philosophicus?}

considers the constant itself as playing the role of a variable and substitutes constant ideas for a given constant idea. He writes 'we consider certain constituents of a proposition as variable and substitute for them sometimes this idea and sometimes that one' (WL, II, §147; also $\$ 69$ and \$108). When he writes 'propositions $\mathrm{A}, \mathrm{B}, \mathrm{C}, \ldots$ in which certain ideas $i, j, \ldots$ are considered as variable', he does not make the modern distinction between variables and constants; in my opinion, his $i, j, \ldots$ are constant, determinate ideas for which we may substitute other determinate ideas. By successive substitutions for 'variable ideas' (constituents), we obtain a whole class of propositions, as Bolzano explains in \$147, as does Wittgenstein in Tractatus, 3.315.

Rolf George and Paul Rusnock, in an article for a dictionary of philosophy, have drawn attention to one of Russell's unpublished papers 'On Substitution' (1904) where a certain notion of variation is in play that R. Monk describes thus:

Instead of working with propositional functions like ' $\mathrm{x}$ is mortal', one works instead with straightforward propositions such as 'Socrates is mortal' and 'Plato is mortal'; and instead of having the notion of a variable ' $x$ ' which can be determined by individuals like Socrates and Plato, one has merely a technique of substituting one individual [name] for another in any given proposition. The advantage of this is that it does away with both the notions of propositional functions and classes in favour of simply propositions. ${ }^{54}$

This is exactly the Bolzanian method of variation. There is nothing similar in Frege. Russell might have discovered it himself-or he could also have found it in Bolzano, an author whom we know Russell read. If there was a transmission of the idea to Wittgenstein, discussion with Russell may have been the route.

Except for additional quotations and references, I have nothing to add to the problem of logical consequence (deducibility, Ableitbarkeit in Bolzano's terminology) and its link to probability. The resemblance between Bolzano and Wittgenstein in this area is, for me, the most important of all and Cohen does not say anything relevant about it. Wittgenstein's account of consequence and probability is a simplification of Bolzano's method. Bolzano explicitly permits the variation of unanalysed propositions, although he does not practise it. There is nothing similar either in Russell or in Frege. It is not impossible that a genius like Wittgenstein found it himself, but it is hard to discard the probability of a Zimmermannian influence.

${ }^{54}$ R. Monk, Bertrand Russell: The Spirit of Solitude (London: Jonathan Cape, 1996), 185. 


\section{Laurence Goldstein}

Bolzanian concepts were discussed in Austrian philosophy since Exner (Brentano and his pupils Kerry, Twardowski, Husserl, Meinong, Höfler et alii; Twardowski's pupil Lukasiewicz has a chapter on Bolzano in Die logischen Grundlagen der Wahrscheinlichkeitsrechnung (1913). As regards the similarities between Bolzano and Tarski, I have written about this. ${ }^{55}$ In Tarski's case, an indirect transmission via Twardowski is not excluded.

University of Hong Kong

${ }_{55}^{5}$ J. Sebestik, Logique et mathématique chez Bernard Bolzano (Paris, Vrin, 1992), 246-7, and, in more detail, in 'Forme, variation et déductibilité dans la logique de Bolzano', Revue d'Histoire des Sciences, 52 (1999), 479-506. 446 